\title{
Effect of Divalent Metal Cations on the Dimerization of OXA-10 and -14 Class D $\beta$-Lactamases from Pseudomonas aeruginosa
}

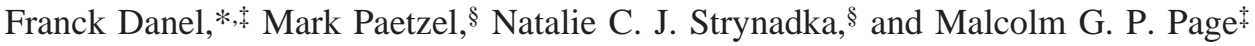 \\ Pharmaceuticals Division, F. Hoffmann-La Roche Ltd., CH-4070 Basel, Switzerland, and Department of Biochemistry and \\ Molecular Biology, University of British Columbia, 2146 Health Sciences Mall, Vancouver, British Columbia V6T 1Z3, Canada
}

Received November 10, 2000; Revised Manuscript Received May 24, 2001

\begin{abstract}
The factors influencing the oligomerization state of OXA-10 and OXA-14 class D $\beta$-lactamases in solution have been investigated. Both enzymes were found to exist as an equilibrium mixture of a monomer and dimer, with a $K_{\mathrm{d}}$ close to $40 \mu \mathrm{M}$. The dimeric form was stabilized by divalent metal cations. The ability of different metal ions to stabilize the dimer was in the following order: $\mathrm{Cd}^{2+}>\mathrm{Cu}^{2+}>$ $\mathrm{Zn}^{2+}>\mathrm{Co}^{2+}>\mathrm{Ni}^{2+}>\mathrm{Mn}^{2+}>\mathrm{Ca}^{2+}>\mathrm{Mg}^{2+}$. The apparent $K_{\mathrm{d}} \mathrm{s}$ describing the binding of $\mathrm{Zn}^{2+}$ and $\mathrm{Cd}^{2+}$ cations to the OXA-10 dimer were 7.8 and $5.7 \mu \mathrm{M}$, respectively. The metal ions had a profound effect on the thermal stability of the protein complex observed by differential scanning calorimetry. The enzyme showed a sharp transition with a $T_{\mathrm{m}}$ of $58.7^{\circ} \mathrm{C}$ in the absence of divalent cations, and an equally sharp transition with a $T_{\mathrm{m}}$ of $78.4{ }^{\circ} \mathrm{C}$ in the presence of a saturating concentration of the divalent cation. The thermal transition observed at intermediate concentrations of divalent metal ions was rather broad and lies between these two extremes of temperature. The equilibrium between the monomer and dimer is dependent on $\mathrm{pH}$, and the optimum for the formation of the dimer shifted from $\mathrm{pH} 6.0$ in the absence of divalent cations to $\mathrm{pH} 7.5$ at saturating concentrations. The $\beta$-lactamase activity increased approximately 2 -fold in the presence of saturating concentrations of zinc and cadmium ions. Reaction with $\beta$-lactams caused a shift in the equilibrium toward monomer formation, and thus an apparent inactivation, but the divalent cations protected against this effect.
\end{abstract}

$\beta$-Lactams have been the most heavily used antibiotics for the past 50 years (1). Many mechanisms of resistance have been developed by bacteria during this period, including efflux pumps, decreased levels of expression of porins, and modification of the PBPs $^{1}$ (penicillin binding proteins, the targets of the $\beta$-lactam antibiotics), but the most prevalent mechanism is the expression of $\beta$-lactamases (2). These enzymes inactivate the antibiotics by hydrolyzing the $\beta$-lactam ring, rendering the antibiotic inactive against PBPs. Four molecular classes of $\beta$-lactamases exist, $\mathrm{A}-\mathrm{D}(3-5)$. The class $\mathrm{A}, \mathrm{C}$, and $\mathrm{D} \beta$-lactamases are serine hydrolyses, while the class B enzymes are metalloenzymes. The number of known $\beta$-lactamases has increased rapidly in the past few years with an evolution in the spectrum of activity (penicillinase, extended-spectrum $\beta$-lactamase, and carbapenemase) that has kept pace with the introduction of new classes of

* To whom correspondence should be addressed. Phone: +41-616880537. Fax: +41-61-6882729. E-mail: franck.danel@roche.com.

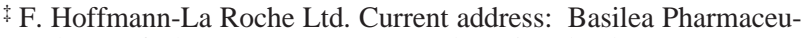
tica Ltd., Postfach 3255, CH-4002 Basel, Switzerland.

$\S$ University of British Columbia.

${ }^{1}$ Abbreviations: PBPs, penicillin binding proteins; $M_{\mathrm{OBS}}$, observed molar mass; $M_{\mathrm{M}}$, molar mass of the monomer; $M_{\mathrm{D}}$, molar mass of the dimer; $M_{\mathrm{APP}}$, apparent molar mass; $E_{\mathrm{D}}$, enzyme concentration in the dimeric form (micromolar); $E_{\mathrm{M}}$, enzyme concentration in the monomeric form (micromolar); $E_{\mathrm{TO}}$, total concentration of enzyme (micromolar); DSC, differential scanning calorimetry; $T_{\mathrm{m}}$, temperature with the maximum heat capacity change; ITC, isothermal titration calorimetry; $\mathrm{pH}_{\mathrm{OPT}}, \mathrm{pH}$ optimum; $\mathrm{p} K_{\mathrm{a} 1}$, acid $\mathrm{p} K_{\mathrm{a}} ; \mathrm{p} K_{\mathrm{a} 2}$, basic $\mathrm{p} K_{\mathrm{a}}$; EDTA, ethylenediaminetetraacetic acid disodium; Tris, tris(hydroxymethyl)aminomethane hydrochloride. $\beta$-lactams (6-10). Thus, there has been considerable interest in elucidating the molecular mechanisms of these enzymes to facilitate the design of mechanism-based inhibitors that could be used to rescue the susceptible antibiotics (11).

Among the serine $\beta$-lactamases, the class $\mathrm{A}$ and class $\mathrm{C}$ enzymes have been extensively studied, whereas relatively little is known about the class D enzymes $(11,12)$. The first structure of a class D enzyme, OXA-10 (PSE-2) $\beta$-lactamase, has only recently been determined $(13,14)$. Unlike the known enzymes from classes $\mathrm{A}$ and $\mathrm{C}$, OXA-10 $\beta$-lactamase was found to be a dimer, both in the crystal structure and in solution (14). The monomer subunit of OXA-10 is organized like the other classes of serine $\beta$-lactamases comprising two domains lying on either side of a $\beta$-sheet that forms the core of the molecule. The OXA-10 enzyme differs significantly from either class $\mathrm{A}$ or class $\mathrm{C}$ enzymes in the $\omega$ loop region, close to the active site. In OXA-10, this loop runs in the opposite direction, and is more compact and shorter than in the class A enzymes. Also, this loop does not contain any acidic residue, equivalent to glutamate 166 of the class $A$ enzymes, that would act as a general base to activate a water molecule for attack on the acyl-enzyme intermediate. The primary sequence showed that two elements ( $\mathrm{S}-\mathrm{X}-\mathrm{X}-\mathrm{K}$ and $\mathrm{K} / \mathrm{R}-\mathrm{T} / \mathrm{S}-\mathrm{G}$ ) of the three identified in the active site in the class $\mathrm{D}$ enzyme were also a common motif among all other serine $\beta$-lactamases. The third element (S-X-V) lacks the polar asparagine residue that is highly conserved in class A (15) and essential for the activity of class $\mathrm{C} \beta$-lactamases (16). The differences between the class D enzyme and the 


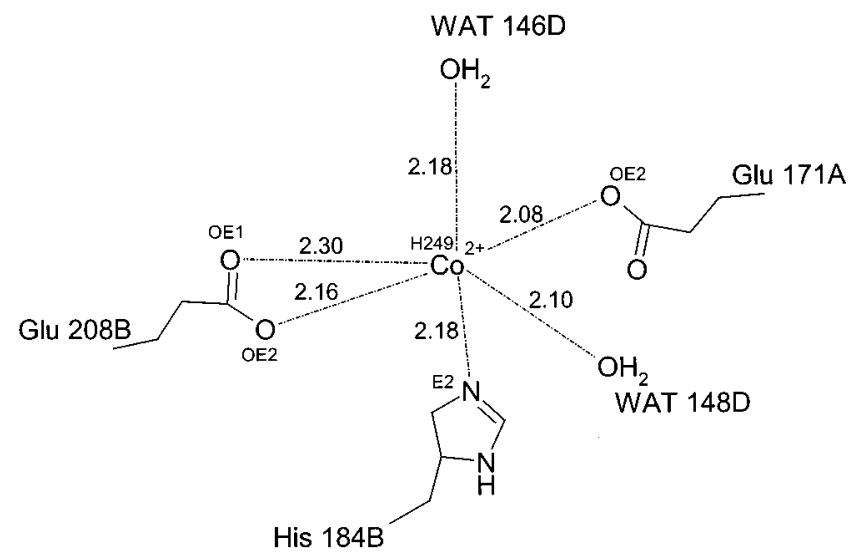

FIGURE 1: One $\mathrm{Co}^{2+}$ binding site from the OXA-10 $\beta$-lactamase dimer interface. Residues in the first OXA-10 molecule are labeled $\mathrm{A}$, and those in the second molecule are labeled B. Water molecules contributing to the dimer interface are labeled D. Two molecules of $\mathrm{Co}^{2+}$ bind per dimer in symmetrical, identical sites. The ligand distances are in angstroms.

enzymes from other classes indicate the different origin of this class and suggest that this class operates a new mechanism for hydrolysis of the $\beta$-lactam ring (14). Kinetic analysis, site-directed mutagenesis, and further crystallographic analysis of complexes with inhibitors or substrate analogues are needed to be able to propose a mechanism.

OXA-10 $\beta$-lactamase is closely related to several ESBL variants that only differ by one or two amino acids, e.g., OXA-11 (Asn143Ser and Gly157Asp), OXA-14 (Gly157Asp), OXA-16 (Ala124Thr and Gly157Asp), and OXA-17 (Asn75Ser) (17-21). A single amino acid change is sufficient to give significant differences in properties. For example, the time course of hydrolysis of some $\beta$-lactams by OXA$10 \beta$-lactamase follows a typical progress curve with many $\beta$-lactams, but some show more complex curves starting with a hyperstoichiometric burst of hydrolysis that decays to a slower steady-state rate. In contrast, the OXA-14 enzyme has exhibited such complex kinetics with every $\beta$-lactam tested so far $(18,23)$. It has been suggested that the burst kinetics could be due to interconversion between monomer and dimer forms that have different specific activities, possibly stimulated by reaction with $\beta$-lactams (24). In this context, the observation that two cobalt ions were located at the interface between the two monomers in the crystal structure (14) suggested that divalent cations might also play a role in the kinetics of these enzymes. The cobalt ions are bound by the side chains of one glutamate and one histidine from one of the subunits and by the side chain of one glutamate from the other molecule. Two water molecules are also involved in the binding in such a way that the cation has 6-fold coordination in octahedral geometry (Figure 1). The involvement of ionizable residues in the binding of the cations that appear to be important for dimer formation clearly suggests that the $\mathrm{pH}$ will also be an important factor in determining the overall activity of the enzyme.

In this study, we have investigated the factors affecting the interconversion between the monomer and dimer forms of OXA-10 and OXA-14. This is important for the proper interpretation of the kinetic studies of these enzymes because the kinetic properties depend strongly on the state of the enzyme. We show that the complex kinetics observed with both enzymes are entirely consistent with the monomer- dimer model and that $\mathrm{Zn}^{2+}$ is the ion most likely to promote the association under physiological conditions.

\section{EXPERIMENTAL PROCEDURES}

Materials. OXA-10 and -14 $\beta$-lactamases were purified by anion and cation exchange as previously described (18, 20,21). Antimicrobials that were tested included ceftazidime (Glaxo-Wellcome, Stevenage, Hertfordshire, U.K.), ceftriaxone (Roche, Basel, Switzerland), ampicillin sodium, carbenicillin disodium, cephaloridine, cephalothin, cloxacillin, methicillin, oxacillin, and penicillin G (Sigma, St. Louis, MO), aztreonam (Bristol-Myers Squibb AG, Baar, Switzerland), and Meropenem (Zeneca, Basiglio, Italy).

Analytical Centrifugation and Size-Exclusion Chromatography. Sedimentation equilibrium experiments were performed in 0.1 M phosphate buffer ( $\mathrm{pH}$ 7.0) using a Beckman Optima XL-A analytical ultracentrifuge with radial scanning at $280 \mathrm{~nm}$. The experimental conditions and data interpretation were as previously described (14).

Size-exclusion chromatography was performed using a Superdex 200 PC 3.2/30 or Superdex 75 PC 3.2/30 gel filtration column (Pharmacia, Dubendorf, Switzerland) connected to a HPLC system (Jasco-Omnilab, Mettmenstetten, Switzerland) at room temperature. The column was equilibrated by running at least 3 times the column volume of buffer through the system prior to loading. Five microliters of the protein solution was injected onto the column, and the sample was eluted at a flow rate of $0.1 \mathrm{~mL} / \mathrm{min}$. The protein elution was monitored by fluorescence at $330 \mathrm{~nm}$ after excitation at $280 \mathrm{~nm}$ (Jasco FP920 intelligent fluorescence detector) and by absorption at $280 \mathrm{~nm}$ (MD 1510, Jasco). The size-exclusion chromatography columns were calibrated using molar mass standards (Bio-Rad, Hercules, CA). The fluorescence and the absorption were calibrated against known concentrations of OXA-10 $\beta$-lactamase determined by quantitative amino acid analysis. The value of the maximum absorption or fluorescence of the peak was used for the determination of enzyme concentration and retention volume (25).

We assume that the change in the molar mass with enzyme concentration is due to a monomer-dimer equilibrium:

$$
2 \mathrm{E}_{\mathrm{M}} \leftrightharpoons \mathrm{E}_{\mathrm{D}}
$$

The observed molar mass $\left(M_{\mathrm{OBS}}\right)$ corresponds to the molar mass intermediate between the molar mass of the monomer $\left(M_{\mathrm{M}}\right)$ and that of the dimer $\left(M_{\mathrm{D}}\right)$ depending of the ratio of the concentration of the enzyme in the dimeric $\left(E_{\mathrm{D}}\right)$ and monomeric $\left(E_{\mathrm{M}}\right)$ form to the total concentration of the enzyme $\left(E_{\mathrm{TOT}}\right)$ :

$$
\begin{gathered}
M_{\mathrm{OBS}}=\left[M_{\mathrm{M}}\left(E_{\mathrm{M}}\right)+M_{\mathrm{D}}\left(E_{\mathrm{D}}\right)\right] / E_{\mathrm{TOT}} \\
E_{\mathrm{TOT}}=E_{\mathrm{M}}+E_{\mathrm{D}} \text { and so } E_{\mathrm{D}}=E_{\mathrm{TOT}}-E_{\mathrm{M}}
\end{gathered}
$$

By incorporation of $E_{\mathrm{D}}$ from eq 2 into eq 1

$$
\begin{aligned}
M_{\mathrm{OBS}} & =\left[M_{\mathrm{M}}\left(E_{\mathrm{M}}\right)+M_{\mathrm{D}}\left(E_{\mathrm{TOT}}-E_{\mathrm{M}}\right)\right] / E_{\mathrm{TOT}} \\
& =\left[\left(M_{\mathrm{M}}-M_{\mathrm{D}}\right)\left(E_{\mathrm{M}}\right) /\left(E_{\mathrm{TOT}}\right)\right]+M_{\mathrm{D}}
\end{aligned}
$$

The equilibrium dissociation constant $K_{\mathrm{d}}$ can be defined as $E_{\mathrm{D}} / E_{\mathrm{M}}^{2}$. 
By incorporation of $E_{\mathrm{D}}$ from eq 2 into $K_{\mathrm{d}}$ and rearrangement of this equation as a quadratic below:

$$
K_{\mathrm{d}}\left(E_{\mathrm{M}}\right)^{2}+E_{\mathrm{M}}-E_{\mathrm{TOT}}=0
$$

This equation possesses only one possible solution $\left(E_{\mathrm{M}} \geq\right.$ $0)$ :

$$
E_{\mathrm{M}}=\left[-1+\left(1+4 K_{\mathrm{d}} E_{\mathrm{TOT}}\right)^{0.5}\right] /\left(2 K_{\mathrm{d}}\right)
$$

By incorporation of eq 4 into eq 3

$$
\begin{aligned}
M_{\mathrm{OBS}}=\left(M_{\mathrm{M}}-M_{\mathrm{D}}\right)\left[-1+\left(1+4 K_{\mathrm{d}} E_{\mathrm{TOT}}\right)^{0.5}\right] / \\
\left(2 K_{\mathrm{d}} E_{\mathrm{TOT}}\right)+M_{\mathrm{D}}
\end{aligned}
$$

eq 5 was used for fitting the results with $M_{\mathrm{M}}, M_{\mathrm{D}}$, and $K_{\mathrm{d}}$ as variables using the Grafit program (26). We assumed that $M_{\mathrm{OBS}}$ corresponds to the apparent molar mass $\left(M_{\mathrm{APP}}\right)$ determined by the calibrated gel filtration column. We also assumed that the $M_{\mathrm{APP}}$ of the dimer deduced from eq 5 should not be obviously twice the one of the monomer, so both molar masses were considered as separate variables. The percentage of dimer was calculated as follows from eq 6 :

$$
\% \text { of dimer }=\left[\left(M_{\mathrm{APP}}-M_{\mathrm{M}}\right) /\left(M_{\mathrm{D}}-M_{\mathrm{M}}\right)\right] \times 100
$$

Calorimetry. The enzyme for differential scanning calorimetry (DSC) was dialyzed against the appropriate buffer and filtered through a $0.2 \mu \mathrm{m}$ pore filter. All sample and reference solutions were degassed for 15 min under vacuum prior to loading. The thermal unfolding was performed using a VP-DSC microcalorimeter (MicroCal, Inc., Northampton, MA). The scanning rate was $1{ }^{\circ} \mathrm{C} / \mathrm{min}$ from 18 to $100{ }^{\circ} \mathrm{C}$ with equilibration for $20 \mathrm{~min}$ at $18{ }^{\circ} \mathrm{C}$. The unfolding parameters were characterized using the program Origin supplied by MicroCal. $T_{\mathrm{m}}$ was defined as the temperature with the maximum heat capacity change.

Isothermal titration calorimetry (ITC) was performed with a MCS titration calorimeter (MicroCal) at $25^{\circ} \mathrm{C}$. The enzyme was first dialyzed overnight, against 500 times its volume of $0.1 \mathrm{M}$ Tris- $\mathrm{H}_{2} \mathrm{SO}_{4}$ (pH 7.0) and $0.1 \mathrm{M} \mathrm{K}_{2} \mathrm{SO}_{4}$ with $2 \mathrm{mM}$ EDTA. The enzyme was then dialyzed extensively against $0.1 \mathrm{M}$ Tris- $\mathrm{H}_{2} \mathrm{SO}_{4}\left(\mathrm{pH} 7.0\right.$ ) and $0.1 \mathrm{M} \mathrm{K}_{2} \mathrm{SO}_{4}$ (four changes against 500 times the enzyme volume) to eliminate the EDTA. The sample was filtered $(0.2 \mu \mathrm{m}$ pore filter $)$ and degassed for $15 \mathrm{~min}$ prior to starting the experiment. During the titration experiment, the enzyme was stirred at $400 \mathrm{rpm}$ in a $1.4 \mathrm{~mL}$ cell at $25^{\circ} \mathrm{C}$, and an injection series $(1 \times 2 \mu \mathrm{L}$ and $49 \times 5 \mu \mathrm{L}$ ) of a $1 \mathrm{mM}$ metal salt solution was carried out using a $250 \mu \mathrm{L}$ syringe with $260 \mathrm{~s}$ between each injection. Control titrations of the metal salt solution into buffer were also performed to correct the data for the heat of dilution of the metal salt solution. The data were analyzed using MicroCal Origin Software with a single- and doublebinding site model $(27,28)$.

$\beta$-Lactamase Activities. The concentrated OXA-10 was added to the buffer, and incubated at room temperature for $20 \mathrm{~min}$. The reaction was started by the addition of nitrocefin ( $0.1 \mathrm{mM}$ final concentration), and the change in absorbance was monitored at $490 \mathrm{~nm}$ using a microplate reader (model 3550 plate recorder, Bio-Rad, Cambridge, MA). For the quantification of OXA-10 in the periplasmic space, the enzyme activity of the crude extract and that of the purified enzyme were compared using $1 \mathrm{mM}$ ampicillin in $0.1 \mathrm{mM}$ Tris- $\mathrm{H}_{2} \mathrm{SO}_{4}$ (pH 7.0). The hydrolyzed $\beta$-lactam was followed by spectrophotometry at $235 \mathrm{~nm}$ (17). The crude extract and the purified $\beta$-lactamase showed hydrolysis rates of 0.04 and $0.03 \Delta \mathrm{OD}_{235} / \mathrm{min}$, respectively, for $0.5 \mu \mathrm{L}$ of enzyme. The crude extract $(250 \mathrm{~mL})$ corresponded to $96 \mathrm{~g}$ of wet cells from a $10 \mathrm{~L}$ fermenter. The concentration of cells in the fermenter is estimated to be $10^{9}$ cells $/ \mathrm{mL}$. Pseudomonas aeruginosa is a rod $(2 \mu \mathrm{m} \times 0.6 \mu \mathrm{m})$ with an approximate volume of $2.3 \times 10^{-12} \mathrm{~mL}(29)$. Using this value leads to an estimated OXA-10 $\beta$-lactamase concentration of $0.4 \mu \mathrm{M}$ in the cell. The periplasmic space is estimated to represent between 5 and $20 \%$ of the cell volume and so to a concentration of OXA-10 $\beta$-lactamase corresponding to $2-8$ $\mu \mathrm{M}(30-33)$.

\section{RESULTS}

Dependence of the Apparent Molar Mass on Protein Concentration. Analytical centrifugation with protein concentrations between 1 and $20 \mu \mathrm{M}$ showed that OXA-10 and OXA-14 have a molar mass of $57 \mathrm{kDa}$, corresponding to the predicted molar mass of a dimer. Concentrations of enzyme lower than $1 \mu \mathrm{M}$ were below the detection limit for the photometer on the analytical centrifuge.

Lower protein concentrations were investigated using sizeexclusion chromatography with detection by fluorescence. The protein molar mass determined by this last method is an apparent molar mass $\left(M_{\mathrm{APP}}\right)$. It corresponds to the actual protein molar mass if the protein has a shape similar to that of the molecules used for calibration and if absorption to the column matrix does not contribute to the behavior during chromatography. The retention times of OXA-10 and OXA14 enzymes, and so the $M_{\mathrm{APP}}$, depended on the enzyme concentration (see Figure 2A). The $M_{\text {APP }}$ of the enzyme was intermediate between that of the dimer and monomer, which reflects the changes in abundance of each species (26). This behavior depends on the rate of conversion between the dimer and monomer and the constant of dissociation $\left(K_{\mathrm{d}}\right)$. Without salt, the observed molar masses were between 11 and $28 \mathrm{kDa}$, depending on the protein concentration (between 3 and $1000 \mathrm{nM}$ ) for OXA-10 and -14. These values were close to half the value expected for the monomer and the dimer from amino acid sequence, but the lower value was close to an $M_{\mathrm{APP}}(12 \mathrm{kDa})$ described before the sequence of the enzyme was known (34). These experiments were repeated in $0.1 \mathrm{M}$ phosphate buffer ( $\mathrm{pH}$ 7.0) and 0.1 M Tris$\mathrm{H}_{2} \mathrm{SO}_{4}$ (pH 7.0) containing $0.3 \mathrm{M} \mathrm{K}_{2} \mathrm{SO}_{4}$ to supress interactions between the column and the protein. Under these conditions, the observed molar mass range was increased to $26-50 \mathrm{kDa}$ according to $\beta$-lactamase concentration (see Figure 2B). The molar masses at low and high concentrations were close to those expected from the amino acid sequence for the monomer $(27.5 \mathrm{kDa})$ and the dimer $(55 \mathrm{kDa})$, respectively. The $M_{\mathrm{APP}}$ for each concentration and conditions was fitted to eq 5 (see Figure 2B).

The effects of different concentrations of metal salts on the $M_{\text {APP }}$ were studied using size-exclusion chromatography (Figure 3 ). The $\beta$-lactamase concentration of $6 \mathrm{nM}$ was chosen because both enzymes are mainly in the monomeric form at this concentration and the fluorescence signal is still 

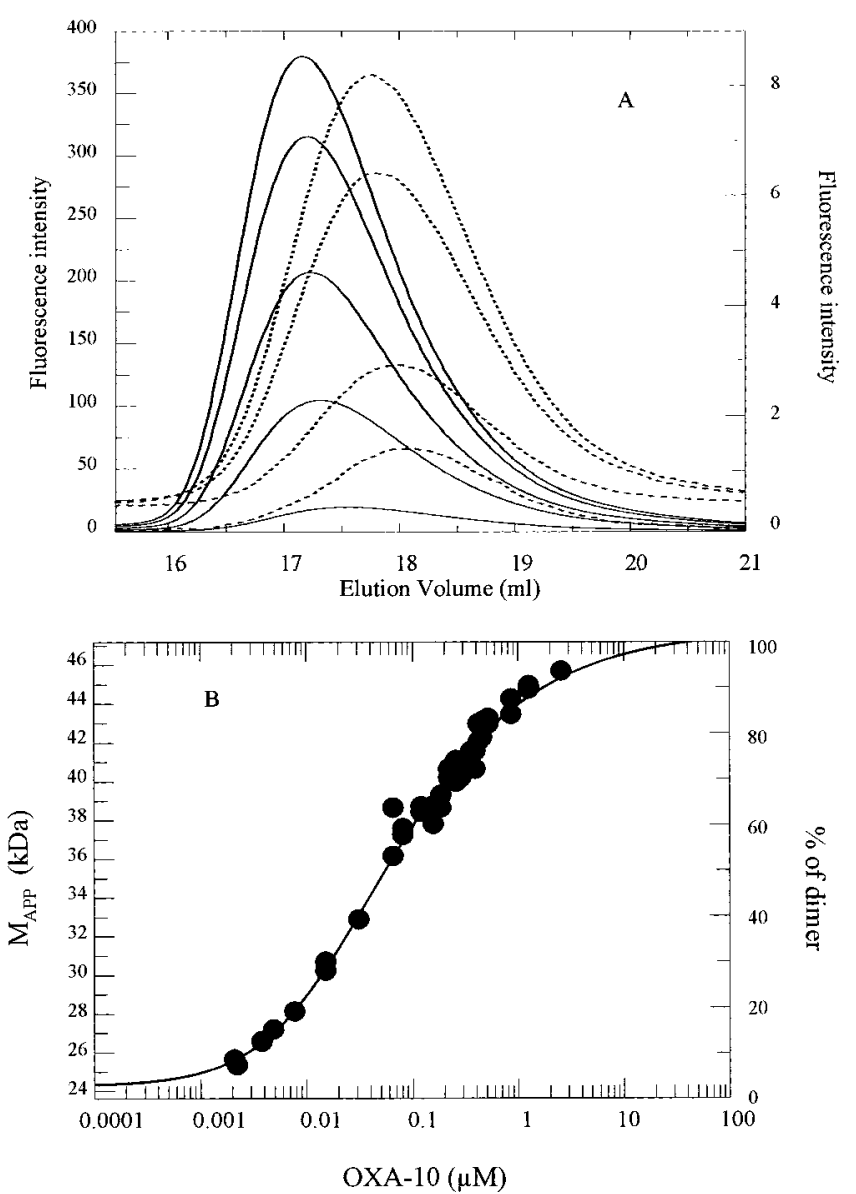

FIGURE 2: (A) Elution volume for different concentrations of OXA$10 \beta$-lactamase on gel filtration chromatography. The enzyme is diluted in $100 \mathrm{mM}$ Tris- $\mathrm{H}_{2} \mathrm{SO}_{4}(\mathrm{pH} 7.0)$ containing $0.3 \mathrm{M} \mathrm{K}_{2} \mathrm{SO}_{4}$ and chromatographed on a Superdex 75 column equilibrated with the same buffer. The solid lines correspond to the left scale, and the dotted lines correspond to the right scale. The intensity is taken to be proportional to the enzyme concentration. (B) OXA-10 $M_{\mathrm{APP}}$ as a function of enzyme concentration in $0.1 \mathrm{M}$ Tris- $\mathrm{H}_{2} \mathrm{SO}_{4}(\mathrm{pH}$ 7.0) containing $0.3 \mathrm{M} \mathrm{K}_{2} \mathrm{SO}_{4}$. The data were fitted with eq 5. The $K_{\mathrm{d}} \mathrm{S}$ of $47 \pm 10$ and $43 \pm 13 \mu \mathrm{M}$ were found for OXA-10 and -14 , respectively. The $M_{\mathrm{APP}}$ of the monomer and dimer were $23 \pm 1$ and $47 \pm 1 \mathrm{kDa}$ for OXA-10 and $26 \pm 1$ and $51 \pm 1 \mathrm{kDa}$ for OXA-14, respectively.

Table 1: Effect of the Enzyme Concentration and $\mathrm{Zn}^{2+}$ on the $\mathrm{p} K_{\mathrm{a} 1}$, $\mathrm{p} K_{\mathrm{a} 2}$, and $\mathrm{pH}$ Optimum ${ }^{a}$

\begin{tabular}{cccccccc}
\hline $\begin{array}{c}\text { [enzyme] } \\
(\mathrm{nM})\end{array}$ & \multicolumn{4}{c}{$\mathrm{no} \mathrm{Zn}$} & & \multicolumn{3}{c}{$0.1 \mathrm{mM} \mathrm{Zn}$} \\
\cline { 2 - 4 } \cline { 6 - 8 } & $\mathrm{pH}_{\mathrm{OPT}}$ & $\mathrm{p} K_{\mathrm{a} 1}$ & $\mathrm{p} K_{\mathrm{a} 2}$ & & $\mathrm{pH}$ & $\mathrm{p} K_{\mathrm{aP} 1}$ & $\mathrm{p} K_{\mathrm{a} 2}$ \\
\hline 6 & 6.0 & $5.6 \pm 0.4$ & $6.6 \pm 0.4$ & & 7.5 & $7.3 \pm 0.2$ & $7.7 \pm 0.2$ \\
15 & 6.0 & $5.1 \pm 0.2$ & $6.6 \pm 0.2$ & & 7.5 & $6.6 \pm 0.2$ & $8.2 \pm 0.2$ \\
30 & 6.5 & $5.7 \pm 0.1$ & $7.2 \pm 0.1$ & & 7.5 & $6.2 \pm 0.1$ & $8.5 \pm 0.2$ \\
60 & 6.5 & $5.5 \pm 0.2$ & $7.5 \pm 0.2$ & & 7.5 & $5.8 \pm 0.2$ & $8.7 \pm 0.2$ \\
\hline
\end{tabular}

${ }^{a}$ The buffer was $50 \mathrm{mM}$ BisTris- $\mathrm{H}_{2} \mathrm{SO}_{4}(\mathrm{pH} 7.0,6.5,6.0$, and 5.5),

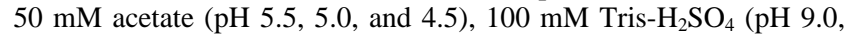
8.5, 8.0, 7.5, and 7.0), or $50 \mathrm{mM}$ Pipes ( $\mathrm{pH} \mathrm{7.0).} \mathrm{In} \mathrm{all} \mathrm{these} \mathrm{buffers,}$ $0.3 \mathrm{M} \mathrm{K}_{2} \mathrm{SO}_{4}$ was added. $\mathrm{pH}$ optimum $\left(\mathrm{pH}_{\mathrm{OPT}}\right)$ with a standard error of $\pm 0.2 . \mathrm{p} K_{\mathrm{a} 1}$ and $\mathrm{p} K_{\mathrm{a} 2}$ correspond to the acid and basic $\mathrm{p} K_{\mathrm{a}}$ of the bell-shaped curve, respectively (Figure 4).

easy to detect (Figure 2). $\mathrm{Cd}^{2+}, \mathrm{Co}^{2+}, \mathrm{Ni}^{2+}, \mathrm{Ca}^{2+}, \mathrm{Mn}^{2+}$, or $\mathrm{Zn}^{2+}$ (chloride or sulfate) at $10 \mathrm{mM}$ in the running buffer gave an $M_{\mathrm{APP}}$ corresponding to the dimer for both enzymes. At this concentration, $\mathrm{Mg}^{2+}$ or EDTA gave an $M_{\mathrm{APP}}$ corresponding to the monomer, whereas $\mathrm{Cu}^{2+}$ created aggregates. At $0.5 \mathrm{mM}$ metal ion, only $\mathrm{Cu}^{2+}, \mathrm{Cd}^{2+}$, and $\mathrm{Zn}^{2+}$ still gave the dimer $M_{\mathrm{APP}}$ and at $0.05 \mathrm{mM}$ only $\mathrm{Cd}^{2+}$ and $\mathrm{Zn}^{2+}$. $\mathrm{NaCl}$ at $5,50,100$, or $250 \mathrm{mM}$ did not affect the $M_{\mathrm{APP}}$ of the enzymes. OXA-10 and -14 responded similarly to all metal salts, and EDTA.

To evaluate in more detail the potential of $\mathrm{Co}^{2+}, \mathrm{Cd}^{2+}$, and $\mathrm{Zn}^{2+}$ to stabilize the dimer, the previous experiment was repeated at different concentrations of metal salts to determine the concentration giving half the enzyme as the dimeric form and the other half as the monomeric form. The concentration of metals needed to stabilize $3 \mathrm{nM}$ enzyme at $50 \%$ dimeric form was $9 \pm 1,15 \pm 1$, and $390 \pm 21 \mu \mathrm{M}$ for $\mathrm{Cd}^{2+}, \mathrm{Zn}^{2+}$, and $\mathrm{Co}^{2+}$, respectively, for OXA-10 and 7 $\pm 1,12 \pm 1$, and $330 \pm 25 \mu \mathrm{M}$ for $\mathrm{Cd}^{2+}, \mathrm{Zn}^{2+}$, and $\mathrm{Co}^{2+}$, respectively, for OXA-14. $\mathrm{Co}^{2+}$ was much less effective than the other two metals. For a higher concentration of enzyme $(6 \mathrm{nM})$, the concentration of $\mathrm{Co}^{2+}$ needed to stabilize at $50 \%$ dimeric was lower, $280 \pm 36$ and $250 \pm 34 \mu \mathrm{M}$ for OXA10 and OXA-14, respectively.

Effect of the $\mathrm{pH}$ on the $M_{A P P}$ of OXA-10 $\beta$-Lactamase. The crystal structure (14) showed that histidine and glutamate are involved in the binding of the metal ions (Figure 1), so the $\mathrm{pH}$ might be expected to play a critical role in the binding. Dimerization of OXA-10 yielded a bell-shaped titration curve (Figure 4). In the absence of divalent cations, the maximum level of dimer formation occurred around $\mathrm{pH} 6.0$ for enzyme concentrations up to $5 \mu \mathrm{M}$ and at $\mathrm{pH} 6.5$ for enzyme concentrations of $>10 \mu \mathrm{M}$. The shift in the $\mathrm{pH}$ optimum was caused by a change in an apparent $\mathrm{p} K_{\mathrm{a}}$ of the alkaline arm with enzyme concentration (Table 1). We estimate on the basis of the $M_{\mathrm{APP}}$ that $\sim 20 \%$ of the protein was present as a dimer at the $\mathrm{pH}$ optimum. In the presence of $0.1 \mathrm{mM}$ $\mathrm{ZnCl}_{2}$, the maximum level of dimer formation occurred at $\mathrm{pH}$ 7.5. The $\mathrm{pH}$ optimum was independent of the enzyme concentration, but the acid $\mathrm{p} K_{\mathrm{a}}$ decreased and the alkaline $\mathrm{p} K_{\mathrm{a}}$ increased with enzyme concentration (Figure 4 and Table 1).

Characterization of $\mathrm{ZnCl}_{2}$ and $\mathrm{CdCl}_{2}$ Binding to Dimeric OXA-10 $\beta$-Lactamase. The $K_{\mathrm{d}}$ for $\mathrm{Zn}^{2+}$ and $\mathrm{Cd}^{2+}$ binding to OXA-10 in the dimeric form was determined in $0.1 \mathrm{M}$ Tris$\mathrm{H}_{2} \mathrm{SO}_{4}\left(\mathrm{pH} 7.0\right.$ ) and $0.1 \mathrm{M} \mathrm{K}_{2} \mathrm{SO}_{4}$ at $25^{\circ} \mathrm{C}$ using isothermal titration calorimetry. This method allowed the titration of the enzyme with the metal salts while the heat change due to the ligand binding was being monitored (Figure 5, top panel). The integrated area of each peak represents the heat generated on binding for each injection (Figure 5, bottom panel) after subtraction of the heat of dilution of the ligand. The heat generated (size of the peak) decreased during titration as the enzyme became saturated by the metal ions. When the enzyme is fully saturated, only a small peak due to the heat of dilution is observed. Using the enthalpy of binding, the number of binding sites and $K_{\mathrm{d}}$ could be deduced (Table 2) by fitting the heat generated during the titration using a one-binding site model (Figure 5, bottom panel). Fitting the data with a two-site model gave a larger error in the thermodynamic parameters, so this model was rejected. The number of binding sites was very close to 1 for both metals, so only one ion binds per monomer (or two metal ions per dimer). The $K_{\mathrm{d}}$ values obtained for $\mathrm{Cd}^{2+}$ and $\mathrm{Zn}^{2+}$ were very similar (5.7 and $7.8 \mu \mathrm{M}$, respectively). The enthalpy was more favorable for $\mathrm{Cd}^{2+}$ than for $\mathrm{Zn}^{2+}$, but the entropy compensates, giving a similar $\Delta G$. 


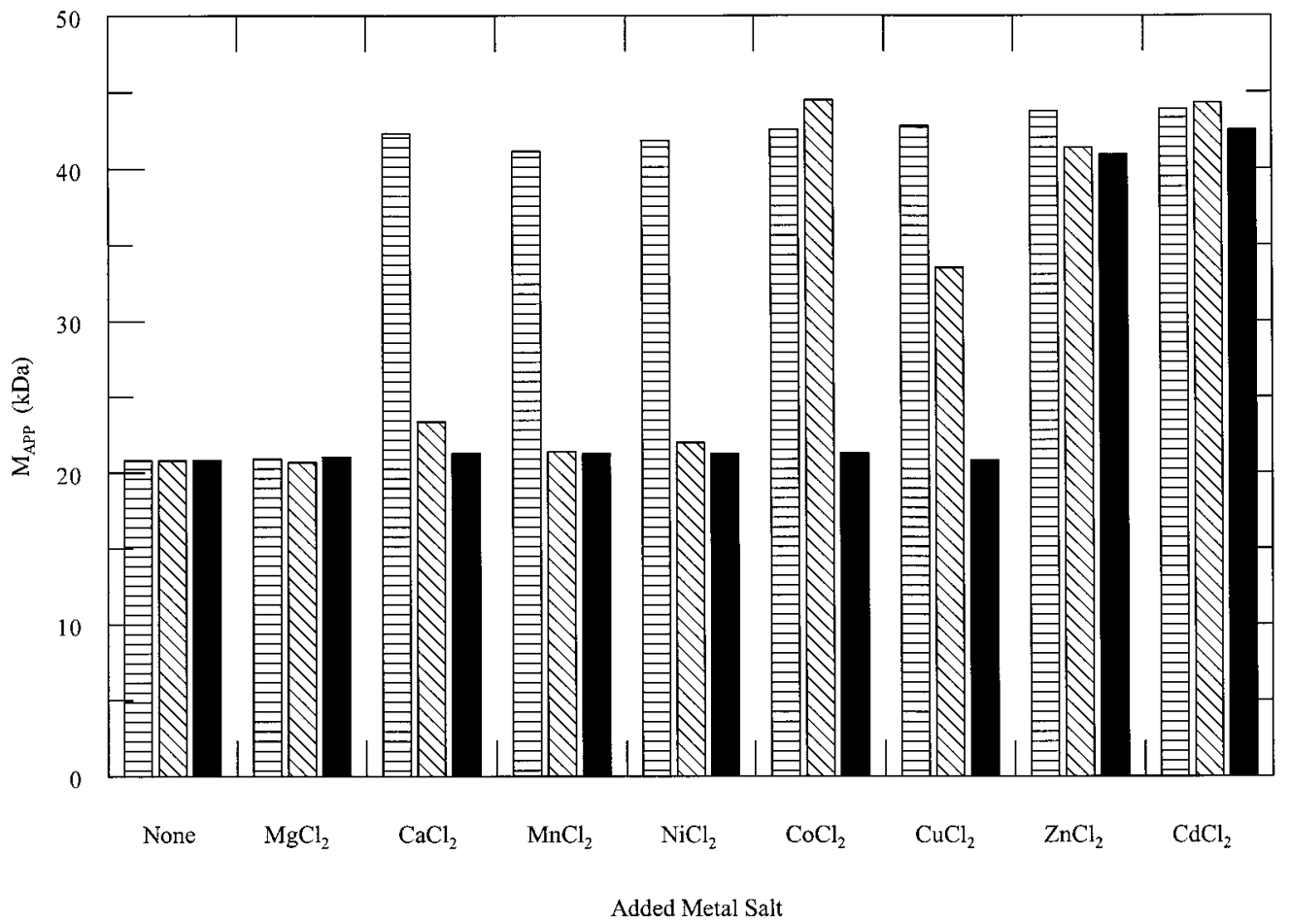

FIGURE 3: Effect of three concentrations of metal on the dimerization of $6 \mathrm{nM} \mathrm{OXA-14} \beta$-lactamase: (striped) 10, (cross-hatched) 0.5, and (black) $0.05 \mathrm{mM}$.

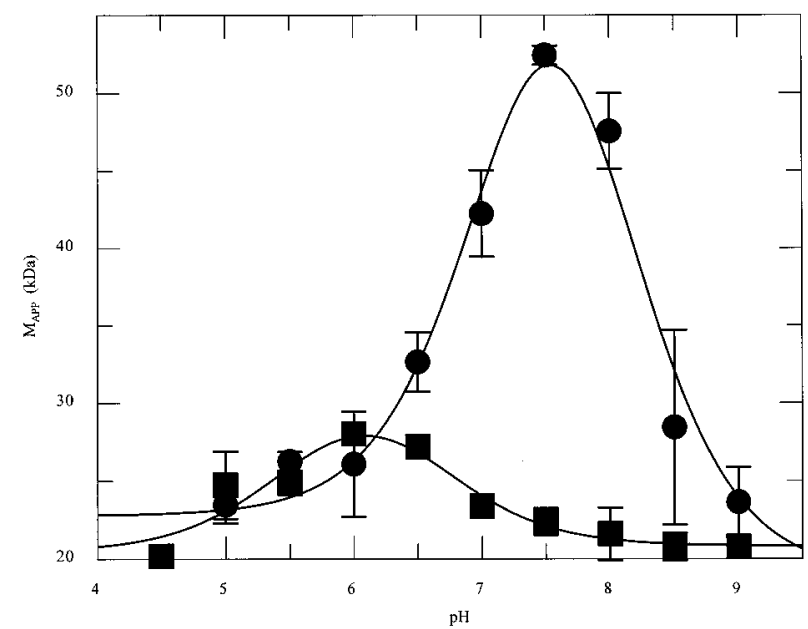

FIGURE 4: Effect of $\mathrm{pH}$ on the apparent molar mass of $6 \mathrm{nM}$ OXA$10 \beta$-lactamase with and without $0.1 \mathrm{mM} \mathrm{ZnCl}_{2}$ : (ם) without $\mathrm{Zn}^{2+}$ and $(\bullet)$ with $0.1 \mathrm{mM} \mathrm{ZnCl}_{2}$.

Effect of the Metal Ions on the Thermal Stability of OXA$10 \beta$-Lactamase. The thermogram of OXA-10 in $0.1 \mathrm{M}$ phosphate buffer ( $\mathrm{pH}$ 6.5) with $0.1 \mathrm{M} \mathrm{K}_{2} \mathrm{SO}_{4}$ gave a sharp peak corresponding to the unfolding, with a $T_{\mathrm{m}}$ of $58.8^{\circ} \mathrm{C}$. The same experiments in $0.1 \mathrm{M}$ Tris- $\mathrm{H}_{2} \mathrm{SO}_{4}(\mathrm{pH}$ 7.0) with $0.1 \mathrm{M} \mathrm{K}_{2} \mathrm{SO}_{4}$ gave a $T_{\mathrm{m}}$ of $57.4{ }^{\circ} \mathrm{C}$. The $\mathrm{pH}$ of the last buffer is more sensitive to the temperature than phosphate buffer, decreasing nearly $1 \mathrm{pH}$ unit with the increase of the temperature from 20 to $57^{\circ} \mathrm{C}(35)$. The difference in stability may thus only reflect the instability of the enzyme at low $\mathrm{pH}$. The addition of $1 \mathrm{mM}$ EDTA to the enzyme did not modify this value, whereas the addition the $0.5 \mathrm{mM} \mathrm{ZnCl} 2$ greatly increased the stability $\left(T_{\mathrm{m}}=71.2^{\circ} \mathrm{C}\right)$. Performing the experiment in $50 \mathrm{mM}$ PIPES (pH 7.8) with $0.1 \mathrm{M} \mathrm{K}_{2-}$ $\mathrm{SO}_{4}$ gave a $T_{\mathrm{m}}$ of $58.7{ }^{\circ} \mathrm{C}$, and the addition of metal salts also increased the stability (see Table 3 ). The effect of metals

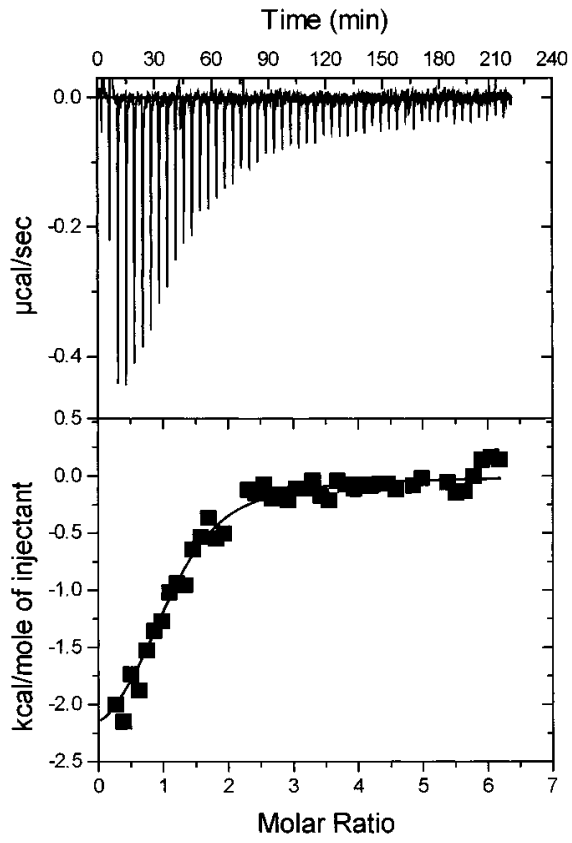

FIGURE 5: Thermogram from an ITC experiment for the binding of $\mathrm{ZnCl}_{2}$ to OXA-10 $\beta$-lactamase in $0.1 \mathrm{M}$ Tris- $\mathrm{H}_{2} \mathrm{SO}_{4}(\mathrm{pH} 7.0$ ) and $0.1 \mathrm{M} \mathrm{K}_{2} \mathrm{SO}_{4}$ at $25^{\circ} \mathrm{C}$. The top panel shows the raw data with the integrated baseline corresponding to 50 injections of $1 \mathrm{mM}$ $\mathrm{ZnCl}_{2}$ to $33 \mu \mathrm{M}$ OXA-10 $\beta$-lactamase. The bottom panel shows the integrated area for each injection, after subtracting the control experiment for the heat of dilution of $\mathrm{ZnCl}_{2}$ to buffer for each injection. The solid line is the best fitted curve obtained with the single-binding site model.

on the thermal stability of the enzyme showed that the enzyme has three different unfolding states depending of the concentration of metal ions. The effect of $\mathrm{Zn}^{2+}$ on OXA-10 (Figure 6) represents a typical behavior observed for this enzyme with the different metals. At low concentrations, or without added metal salt, a sharp peak (type A) with a $T_{\mathrm{m}}$ 
Table 2: Thermodynamic Parameters for Metals Binding to OXA-10 $\beta$-Lactamase in $0.1 \mathrm{M}$ Tris- $\mathrm{H}_{2} \mathrm{SO}_{4}(\mathrm{pH} 7.0$ ) and $0.3 \mathrm{M}$ $\mathrm{K}_{2} \mathrm{SO}_{4}$ at $25^{\circ} \mathrm{C}$

\begin{tabular}{lcc}
\hline & $\mathrm{Zn}^{2+}$ & $\mathrm{Cd}^{2+}$ \\
\hline$N^{\mathrm{a}}(\mathrm{mol} / \mathrm{mol}$ of monomer $)$ & $1.1 \pm 0.1$ & $1.2 \pm 0.1$ \\
$K_{\mathrm{d}}(\mu \mathrm{M})$ & $7.8 \pm 1.8$ & $5.7 \pm 1.1$ \\
$\Delta H(\mathrm{kcal} / \mathrm{mol})$ & $-2.6 \pm 0.2$ & $-4.5 \pm 0.5$ \\
$\Delta G(\mathrm{kcal} / \mathrm{mol})^{b}$ & -7.0 & -7.1 \\
$-T \Delta S(\mathrm{kcal} / \mathrm{mol})^{b}$ & -4.4 & -2.6 \\
\hline
\end{tabular}

${ }^{a} N$ corresponds to the stoichiometry of the ligand and enzyme. ${ }^{b}$ These values are calculated from $K_{\mathrm{d}}$ and $\Delta H$ using the equation $\Delta G$ $=R T \ln \left(K_{\mathrm{d}}\right)=\Delta H-T \Delta S$.

Table 3: Effect of Metals and EDTA on the Stability of $4.5 \mu \mathrm{M}$ OXA-10 $\beta$-Lactamase in $50 \mathrm{mM}$ PIPES (pH 7.8) and $0.1 \mathrm{M} \mathrm{K}_{2} \mathrm{SO}_{4}$

\begin{tabular}{lccc}
\hline \multicolumn{1}{c}{ metal } & concentration $(\mathrm{mM})$ & $T_{\mathrm{m}}{ }^{a}\left({ }^{\circ} \mathrm{C}\right)$ & peak shape $^{b}$ \\
\hline- & - & 58.7 & A \\
EDTANa & 1.0 & 58.3 & A \\
$\mathrm{MgCl}_{2}$ & 0.1 & 58.8 & A \\
& 0.5 & 58.8 & A \\
$\mathrm{MnCl}_{2}$ & 0.5 & 59.5 & A \\
$\mathrm{NiCl}_{2}$ & 0.1 & 60.2 & A \\
& 0.5 & 69.7 & B \\
$\mathrm{CoCl}_{2}$ & 5.0 & 75.0 & B \\
& 0.1 & 60.7 & A \\
$\mathrm{CdCl}_{2}$ & 0.5 & 75.5 & B \\
& 2.5 & 78.8 & $\mathrm{C}$ \\
$\mathrm{ZnCl}_{2}$ & 0.1 & 62.3 & B \\
& 0.5 & 79.5 & $\mathrm{C}$ \\
$\mathrm{K}_{2} \mathrm{SO}_{4}$ & 0.1 & 64.0 & B \\
$\mathrm{NaCl}_{2}$ & 0.5 & 78.4 & C \\
& 300 & 61.3 & A \\
& 0.5 & 58.4 & A \\
& 20 & 58.4 & A \\
& 100 & 58.7 & A \\
\hline
\end{tabular}

${ }^{a}$ The $T_{\mathrm{m}}$ value is within $\pm 0.3{ }^{\circ} \mathrm{C} .{ }^{b}$ Peak shape A corresponds to a sharp peak observed up to $61^{\circ} \mathrm{C}$, B to a large unfolding peak observed between 60 and $75^{\circ} \mathrm{C}$, and $\mathrm{C}$ to an unfolding peak observed at high temperatures (Figure 6).

close to $58.7^{\circ} \mathrm{C}$ was obtained. At high concentrations, a sharp peak (type C) was again observed around $78-79.5$ ${ }^{\circ} \mathrm{C}$ that corresponded to an increase in $T_{\mathrm{m}}$ of close to $20{ }^{\circ} \mathrm{C}$ in comparison to peak A. At intermediate concentrations, a broad peak was always observed in the temperature range between 60 and $75^{\circ} \mathrm{C}$. This featureless peak (type B) with a $T_{\mathrm{m}}$ at a temperature higher than that observed with the enzyme alone seems to correspond to a transition or equilibrium between the type $\mathrm{A}$ and type $\mathrm{C}$ conformations.

At $\mathrm{pH} 6.5,7.0$, or 7.8 , the transition peak did not appear during a second scan after the solution was heated to just after the end of the first transition. These results indicate that the unfolding transition was not reversible. $\mathrm{NaCl}$ did not show any effect up to $0.1 \mathrm{M}$; however, an increase in stability is observed for a concentration of $1 \mathrm{M}$, and this is also observed with a high concentration of $\mathrm{K}_{2} \mathrm{SO}_{4}$ (Table 3).

Effect of $\beta$-Lactams on the Apparent Molar Mass. Ampicillin, carbenicillin, ceftazidime, and Meropenem caused a decrease in the $M_{\mathrm{APP}}$ at a high concentration of OXA-10 or -14 $\beta$-lactamase $\left(1.2 \mu \mathrm{M}\right.$ in $0.1 \mathrm{M}$ Tris- $\mathrm{H}_{2} \mathrm{SO}_{4}$ with $0.3 \mathrm{M}$ $\mathrm{K}_{2} \mathrm{SO}_{4}$ ) in the absence of divalent cations in the elution buffer (see Table 4). We interpret this as a shift in the monomerdimer equilibrium toward the monomer. OXA-14 was generally less affected than OXA- 10 by $\beta$-lactams. For both

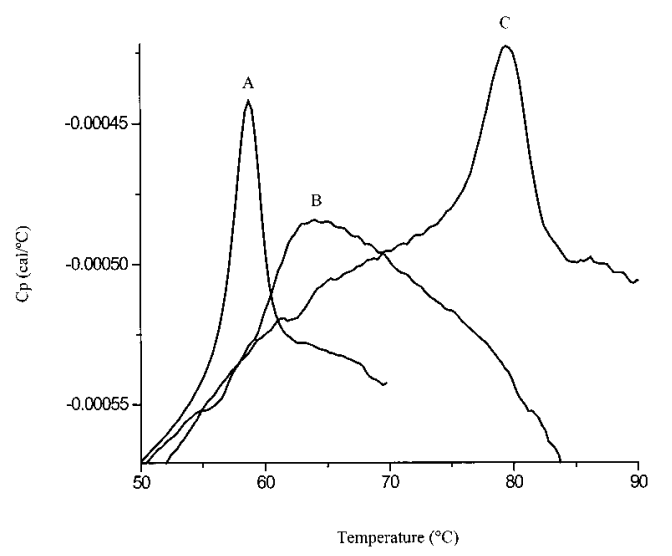

FIGURE 6: DSC scans of $4.5 \mu \mathrm{M}$ OXA-10 $\beta$-lactamase in $50 \mathrm{mM}$ PIPES (pH 7.8) and $0.1 \mathrm{M} \mathrm{K}_{2} \mathrm{SO}_{4}$ with $0,0.1$, and $0.5 \mathrm{mM} \mathrm{ZnCl}_{2}$ (from left to right). These DSC endotherms show the nonreversible unfolding of the enzyme with $T_{\mathrm{m}}$ values of $58.7,64.0$, and $78.4^{\circ} \mathrm{C}$ for $0,0.1$, and $0.5 \mathrm{mM} \mathrm{ZnCl}_{2}$, respectively. Curve A corresponds to the typical sharp peak observed up to $61^{\circ} \mathrm{C}$ for the enzyme by itself and with some metals such as $0.1 \mathrm{mM} \mathrm{Co}^{2+}$ and $\mathrm{Ni}^{2+}$ (see Table 3). DSC curve B corresponds to a typical large unfolding peak observed for the transition between 60 and $75^{\circ} \mathrm{C}$ when metals are added (for example, $0.1 \mathrm{mM} \mathrm{Cd}^{2+}$ and $\mathrm{Zn}^{2+}$, and $0.5 \mathrm{mM} \mathrm{Co}^{2+}$ ). Endotherm $\mathrm{C}$ represents a typical unfolding peak observed at high temperatures for the high concentration of $\mathrm{Zn}^{2+}, \mathrm{Co}^{2+}$, and $\mathrm{Cd}^{2+}$.

enzymes, the carbapenem Meropenem was the most potent in converting the dimeric form of the enzyme to the monomeric form. The $M_{\mathrm{APP}}$ of OXA-14 was more affected by ceftazidime than by the penicillins that were tested, whereas OXA-10 was strongly affected by the two penicillins.

The $M_{\text {APP }}$ at low concentrations of OXA-14 stabilized in dimeric form by $\mathrm{Zn}^{2+}\left(6 \mathrm{nM}\right.$ enzyme in $0.1 \mathrm{M}$ Tris- $\mathrm{H}_{2} \mathrm{SO}_{4}$ with $0.3 \mathrm{M} \mathrm{K}_{2} \mathrm{SO}_{4}$ with $0.1 \mathrm{mM} \mathrm{ZnSO}_{4}$ ) was not significantly affected by any of the $\beta$-lactams. With OXA-10, only Meropenem and carbenicillin evolved significant reaction under these conditions (Table 4).

Effect of Divalent Cations on $\beta$-Lactamase Activity. Figure 7 shows the effect of some divalent cations on the hydrolysis of nitrocefin by OXA-10 and -14. $\mathrm{Cd}^{2+}, \mathrm{Zn}^{2+}$, and $\mathrm{Ni}^{2+}$ have the most potent effect and increase the activity 2 -fold. These metals reached their maximum effect between 0.2 and $1 \mathrm{mM}$. There was some loss of activity at higher concentrations. $\mathrm{Co}^{2+}$ increased the activity to a similar level, but the maximum effect was obtained at only $2 \mathrm{mM}$. EDTA, $\mathrm{Mg}^{2+}$, $\mathrm{Ca}^{2+}$, and $\mathrm{K}^{+}$did not show any effect in comparison to the reference. Loss of activity was observed for $\mathrm{KCl}$ or $\mathrm{NaCl}$ at concentrations of $>4 \mathrm{mM}$. OXA-14 responded in the same way as OXA-10 to the presence of metal ions.

\section{DISCUSSION}

Changes in oligomerization state with protein concentration similar to those observed with OXA-10 and -14 $\beta$-lactamase have been reported several times, for example, for hemoglobin and phage $\varnothing 29$ protein p6 $(25,36)$. In the case of OXA-10, the dimer X-ray structure showed two metal ion binding sites formed at the interface between each monomer (see Figure 1). The results confirm that the dimeric enzyme is stabilized by metal ions in solution. The ability of different metal ions to stabilize the dimer did not show any correlation with the cationic radius of the metal ion. All the ions that were studied can bind ligands via octahedral coordination as observed for cobalt in the crystal structure 
Table 4: Effect of $\beta$-Lactams in the Running Buffer on the $M_{\mathrm{APP}}$ of $1.2 \mu \mathrm{M}$ and $6 \mathrm{nM} \mathrm{OXA}-10$ and $-14 \beta$-Lactamase in Tris- $\mathrm{H}_{2} \mathrm{SO}_{4}(\mathrm{pH} 7.0)$ and $0.3 \mathrm{M} \mathrm{K}_{2} \mathrm{SO}_{4}{ }^{a}$

\begin{tabular}{|c|c|c|c|c|c|c|c|c|}
\hline \multirow[b]{3}{*}{$\beta$-lactam } & \multicolumn{4}{|c|}{$1.2 \mu \mathrm{M} \beta$-lacatamase without $\mathrm{Zn}^{2+}$} & \multicolumn{4}{|c|}{$6 \mathrm{nM} \beta$-lactamase with $0.1 \mathrm{mM} \mathrm{Zn}^{2+}$} \\
\hline & \multicolumn{2}{|c|}{ OXA-10 } & \multicolumn{2}{|c|}{ OXA-14 } & \multicolumn{2}{|c|}{ OXA-10 } & \multicolumn{2}{|c|}{ OXA-14 } \\
\hline & $M_{\mathrm{APP}}(\mathrm{kDa})$ & $\%$ dimer & $M_{\mathrm{APP}}(\mathrm{kDa})$ & $\%$ dimer & $M_{\mathrm{APP}}(\mathrm{kDa})$ & $\%$ dimer & $M_{\mathrm{APP}}(\mathrm{kDa})$ & $\%$ dimer \\
\hline ampicillin $^{a}$ & 33.5 & 42 & 41.8 & 77 & 38.7 & 64 & 40.7 & 72 \\
\hline carbenecillin & 32.8 & 39 & 40.2 & 70 & 36.6 & 55 & 41.6 & 76 \\
\hline ceftazidime & 38.7 & 64 & 39.6 & 68 & 41.4 & 75 & 40.0 & 69 \\
\hline Meropenem & 33.5 & 42 & 37.0 & 57 & 31.7 & 34 & 33.5 & 72 \\
\hline none & 46.2 & 96 & 45.7 & 94 & 40.2 & 70 & 41.1 & 74 \\
\hline
\end{tabular}

${ }^{a}$ The concentration of $\beta$-lactams in the running buffer was $1 \mathrm{mM}$ for ampicillin, carbenicillin, Meropenem, and ceftazidime.

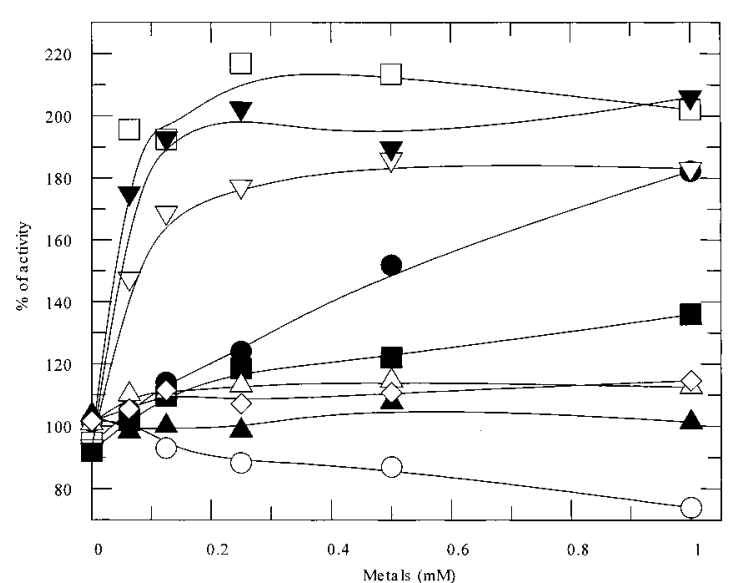

FIGURE 7: Activity of OXA-10 $\beta$-lactamase vs nitrocefin in 0.1 $\mathrm{mM}$ Tris- $\mathrm{H}_{2} \mathrm{SO}_{4}(\mathrm{pH} 7.0)$ and $0.3 \quad \mathrm{M} \mathrm{K}_{2} \mathrm{SO}_{4}$ with different concentrations of metals or EDTA: $(\square) \mathrm{CdCl}_{2},(\bullet) \mathrm{CoCl}_{2},(\nabla)$ $\mathrm{CuCl}_{2},(\boldsymbol{\Delta}) \mathrm{EDTANa}_{2},(\bigcirc) \mathrm{KCl},(\triangle) \mathrm{MgCl}_{2},(\diamond) \mathrm{MnCl}_{2},(\mathbf{\square}) \mathrm{NiCl}_{2}$, and $(\boldsymbol{\nabla}) \mathrm{ZnCl}_{2}$. The concentration of $\mathrm{KCl}$ is 10 times higher than the one written in the graph.

(Figure 1). $\mathrm{Cu}^{2+}$ can use this coordination but in a distorted structure, which might explain the problems with enzyme stability observed in the presence of this ion. The metals can be classified as forming hard or soft acid cations in terms of Lewis-base theory (37). Hard acid metal cations tend to be small, with high positive charge, and do not easily possess unshared valence electrons. Soft acid metal cations tend to be large, with low positive charge, and readily polarizable with unshared electrons that are easily removed or are in orbitals that are readily distorted. The hard acid metal cations are usually held by electrostatic forces with oxygen as the preferred ligand. Soft acid metal cations bind by forming partially covalent bonds (e.g., $\pi$ bonds) with nitrogen or sulfur, forming a strong complex. $\mathrm{Ca}^{2+}, \mathrm{Mg}^{2+}$, and $\mathrm{Mn}^{2+}$ are typical hard acid cations; $\mathrm{Ni}^{2+}, \mathrm{Co}^{2+}, \mathrm{Cu}^{2+}$, and $\mathrm{Zn}^{2+}$ are borderline, and $\mathrm{Cd}^{2+}$ is a typical soft acid metal cation. Clearly, OXA-10 has a preference for soft, or borderline, acid metal cations in comparison to the hard acid cations.

The $K_{\mathrm{d}}$ observed for the dimeric form of the OXA-10 enzyme at $\mathrm{pH} 7.0$ for $\mathrm{Cd}^{2+}$ and $\mathrm{Zn}^{2+}$ is lower than the $K_{\mathrm{d}}$ of the dimer-monomer equilibrium. The concentration of these two metals needed to stabilize the dimeric form is thus mainly determined by the affinity of the metal for the dimer, and not the $K_{\mathrm{d}}$ of the dimer-monomer equilibrium. These observations contrasted with the data obtained for $\mathrm{Co}^{2+}$, where the $K_{\mathrm{d}}$ for binding is higher than the $K_{\mathrm{d}}$ of the dimermonomer equilibrium. In such a case, the position of this dimerization equilibrium will strongly influence the binding of cation. Interestingly, the $K_{\mathrm{d}} \mathrm{S}$ of $\mathrm{Zn}^{2+}$ and $\mathrm{Cd}^{2+}$ (and so
$\Delta G)$ are close to each other, while the enthalpies $(\Delta H)$ are quite different. This suggests that entropy drives the binding for $\mathrm{Zn}^{2+}$, whereas binding of $\mathrm{Cd}^{2+}$ is enthalpy-driven. This results can be perhaps explained by the chemical properties of the metals: $\mathrm{Zn}^{2+}$ is less polarizable than $\mathrm{Cd}^{2+}$ and so organizes more water molecules around itself.

The $\mathrm{pH}$ dependence of the dimer-monomer equilibrium is very suggestive of the ionization of the amino acids observed at the dimer interface in the crystal structure. The acid arm $\left(\mathrm{p} K_{\mathrm{a} 1}\right)$ could be due to the protonation of glutamate [e.g., glutamate 208 and 171 (Figure 1)]. The basic arm ( $\mathrm{p} K_{\mathrm{a} 2}$ $=6.6-7.5$ ) can be attributed to deprotonation of the histidine $\left(\mathrm{p} K_{\mathrm{a}}=6.0\right)$ at high $\mathrm{pH}$ [e.g., histidine 184 (Figure 1)]. At the extremes of the $\mathrm{pH}$ range, the salt bridge between glutamate 171 of one monomer and histidine 204 from the other monomer that is necessary for dimer stabilization will be lost due to protonation and deprotonation, respectively, of these two residues. Binding of a metal ion clearly perturbs the ionization reactions. The $\mathrm{pH}_{\mathrm{OPT}}$ of formation of dimer $\left(\mathrm{pH}_{\text {OPT }} 7.5\right)$ in the presence of $\mathrm{Zn}^{2+}$ was higher than that without ( $\mathrm{pH}_{\mathrm{OPT}}$ 6.0-6.5). At lower $\mathrm{pH}$, the metals did not bind and the proportion of dimer is the same as observed with the apoenzyme. This is because the histidine at $\mathrm{pH}<6.5$ is mainly positively charged and so not able to bind metal ions. At higher $\mathrm{pH}$, the histidine loses its positive charge, and thus weakens the dimerization of the apoenzyme, but this favors the binding of a divalent cation and, thus, formation of the more stable dimer-metal ion complex. If the $\mathrm{pH}$ becomes too high, the metal ions are precipitated as their hydroxides and the dimer again is like that formed from the apoenzyme.

Differential scanning calorimetry showed that the metal ion has a profound effect on the thermal stability of the dimer. As the equilibrium between the monomer and dimer seems to be quite rapidly reversible, it is quite possible that the dimer could be dissociated into monomers and that these will denature individually. If the monomer is less stable than the dimer, the equilibrium will be displaced toward the monomer. This mechanism can explain why a single $T_{\mathrm{m}}$ is observed for the apoenzyme and that the concentration of enzyme has no effect on the $T_{\mathrm{m}}$. Following this hypothesis, we can stipulate that the peak with a $T_{\mathrm{m}}$ of $58.7^{\circ} \mathrm{C}$ would correspond to the monomer. The highest peak with a $T_{\mathrm{m}}$ of $\sim 78{ }^{\circ} \mathrm{C}$ corresponds to the dimer stabilized by the metal ion. The broad peak (B) observed with intermediate concentrations of metal reflects a mixed population comprised of monomers, metal-free dimers, and dimers complexed with cations.

Divalent metals such as $\mathrm{Co}^{2+}, \mathrm{Cd}^{2+}, \mathrm{Zn}^{2+}, \mathrm{Ni}^{2+}$, and $\mathrm{Mn}^{2+}$ increased the activity of OXA-10 and -14 against nitrocefin 
$\sim 2$-fold. A very good correlation was observed between the ability of the cations to stabilize the dimer at low concentrations and the ones that were able to keep the high activity. The higher activity for OXA-10 and OXA-14 $\beta$-lactamase can be explained by the fact that the dimer was more active against nitrocefin than the monomer. OXA-10 has previously been reported to give burst kinetics for some $\beta$-lactams (including ampicillin, cephaloridine, carbenicillin, oxacillin, and cloxacillin), while for OXA-14, all $17 \beta$-lactams that were tested gave biphasic curves $(18,22)$. The burst kinetics have been attributed to interconversion between a more active dimer and a less active monomer. We are able to confirm that the (metal-complexed) dimer is the more active species. Further, we have shown that reaction with $\beta$-lactams does indeed have a strong effect on the monomer-dimer equilibrium (Table 4), in particular, shifting the position toward the less active monomer. It remains to be seen whether dimer-monomer interconversion is an integral part of the catalytic mechanism or only a consequence of conformational changes accompanying some of the reaction steps.

OXA-10 $\beta$-lactamase is found predominately in $P$. aeruginosa $(34,38)$, only once appearing in Enterobacteriaceae (39). P. aeruginosa is found in hospitals but also in drain and sewage water where the concentration of metals can be high. In humans, $P$. aeruginosa can cause serious infections in burns, wounds, eyes, skin, and the respiratory and urinary tracts. The septicemia occur through the overspill from other loci or after surgery, and the mortality rate is high. With its periplasmic location, the $\beta$-lactamase will be situated at a metal ion concentration similar that of its environment. In this context, the concentration of metals in the plasma can be taken as an example, but the concentration of metals in the human body can vary with the environment and in some cases with age. The concentrations of divalent metal ions such as $\mathrm{Mg}^{2+}, \mathrm{Ca}^{2+}, \mathrm{Zn}^{2+}, \mathrm{Cu}^{2+}, \mathrm{Mn}^{2+}, \mathrm{Co}^{2+}, \mathrm{Cd}^{2+}$, and $\mathrm{Ni}^{2+}$ in plasma are $1000,3000,20,15,2,0.8,0.02$, and $<0.005$ $\mu \mathrm{M}$, respectively $(40-42)$. The only metals that have the affinity in the correct concentration range to bind to OXA10 are $\mathrm{Zn}^{2+}, \mathrm{Cu}^{2+}$, and $\mathrm{Ca}^{2+}$, and of these, $\mathrm{Zn}^{2+}$ seems to be the most likely to be involved. The concentration of OXA$10 \beta$-lactamase in $P$. aeruginosa PU21 (pMLH51) periplasmic space was estimated to be $2-8 \mu \mathrm{M}$. Plasmid pMLH51 was not an overproducer, but it was found in a clinical isolate and transferred to $P$. aeruginosa PU21 by transconjugation $(17,39)$. Under this condition, the concentration of enzyme determined here very likely corresponds to a concentration of $\beta$-lactamase found in a clinical isolate. This concentration was very close to the value previously estimated for OXA$14 \beta$-lactamase $(8 \mu \mathrm{M})$ in $P$. aeruginosa $(24)$, but much lower than the concentration of $0.4-0.9 \mathrm{mM}$ reported in Serratia marcescens for another class of $\beta$-lactamases (43). At the estimated concentration, the enzyme is already mainly in the dimeric form (see Figure 2) and the metal should have only a small effect on the dimerization, but it may protect the dimer from conversion to the monomer in the presence of $\beta$-lactams.

In conclusion, OXA-10 and OXA-14 are dimers at high concentrations (such as in stock solutions) but are monomers at the concentration at which assays are usually performed. The burst kinetics, which can now be clearly attributed to a shift in the monomer-dimer equilibrium after dilution of the enzyme into the reaction mixture, are something of an artifact of the experimental design. The kinetics of $\beta$-lactam hydrolysis are complicated, and a detailed study of the kinetic properties of these enzymes taking into account all the various species (monomer, monomer-metal, dimer, and dimer-metal, with and without $\beta$-lactam) is in progress. The kinetic properties of the monomeric enzyme with or without metals can be easily determined, but this is not the relevant enzyme species formed in the cell, where the enzyme is expected to be in the dimeric form. The kinetic properties of the dimeric enzyme are more complex. For the dimer in the absence of divalent metal cations, they will be more difficult to study because the OXA-10 and OXA-14 dimers are destabilized by $\beta$-lactam. Nevertheless, the results presented herein give a framework within which the data can be analyzed.

The reversible equilibrium between the monomer and dimer should be expected for enzymes closely related to OXA-10 and -14 that possess the histidine and two glutamates at the correct position (e.g., OXA-5, -7, -11, -13, -16, -17, -19 , and -28). No other class $\mathrm{D} \beta$-lactamases described up to now possess this feature. The OXA-2, $-3,-15$, and -21 enzymes have glutamate 171 and histidine 184 replaced with aspartate and arginine, respectively. The large size and fixed positive charge at physiological $\mathrm{pH}$ of arginine exclude the possibility of any cation binding, but the dimerization can probably still occur using a direct salt bridge between these two residues. This could explain the higher $M_{\mathrm{APP}}$ described for OXA-2 and also the reported dimerization of OXA-3 $\beta$-lactamase (44).

\section{ACKNOWLEDGMENT}

We thank Dr. Francis Mueller for the analytical centrifugation experiment and Eric Andrè Kusznir for his technical help.

\section{REFERENCES}

1. Livermore, D. M. (1995) Clin. Microbiol. Rev. 8, 557-584.

2. Livermore, D. M. (1996) Scand. J. Infect. Dis. Suppl. 101, 33-43.

3. Ambler, R. P. (1980) Philos. Trans. R. Soc. London, Ser. B, 321-331.

4. Ambler, R. P., Coulson, A. F., Frère, J. M., Ghuysen, J. M., Joris, B., Forsman, M., Levesque, R. C., Tiraby, G., and Waley, S. G. (1991) Biochem. J. 276, 269-270.

5. Ouellette, M., Bissonnette, L., and Roy, P. H. (1987) Proc. Natl. Acad. Sci. U.S.A. 84, 7378-7382.

6. Naas, T., and Nordmann, P. (1999) Curr. Pharm. Des. 5, 865879.

7. Bou, G., Oliver, A., and Martinez-Beltran, J. (2000) Antimicrob. Agents Chemother. 44, 1556-1561.

8. Afzal-Shah, M., Villar, H. E., and Livermore, D. M. (1999) J. Antimicrob. Chemother. 43, 127-131.

9. Afzal-Shah, M., Woodford, N., and Livermore, D. M. (2001) Antimicrob. Agents Chemother. 45, 583-588.

10. Donald, H. M., Scaife, W., Amyes, S. G., and Young, H. K. (2000) Antimicrob. Agents Chemother. 44, 196-199.

11. Page, M. G. P. (2000) Drug Resist. Updates 3, 109-125.

12. Knox, J. R. (1995) Antimicrob. Agents Chemother. 39, 25932601.

13. Golemi, D., Maveyraud, L., Vakulenko, S., Tranier, S., Ishiwata, A., Kotra, L. P., Samama, J.-P., and Mobashery, S. (2000) J. Am. Chem. Soc. 122, 6132-6133.

14. Paetzel, M., Danel, F., de Castro, L., Mosimann, S. C., Page, M. G., and Strynadka, N. C. J. (2000) Nat. Struct. Biol. 7, 918-925. 
15. Matagne, A., and Frere, J. M. (1995) Biochim. Biophys. Acta 1246, 109-127.

16. Dubus, A., Normark, S., Kania, M., and Page, M. G. (1995) Biochemistry 34, 7757-7764.

17. Hall, L. M., Livermore, D. M., Gur, D., Akova, M., and Akalin, H. E. (1993) Antimicrob. Agents Chemother. 37, 1637-1644.

18. Danel, F., Hall, L. M., Gur, D., and Livermore, D. M. (1995) Antimicrob. Agents Chemother. 39, 1881-1884.

19. Danel, F., Hall, L. M., Gur, D., and Livermore, D. M. (1997) Antimicrob. Agents Chemother. 41, 785-790.

20. Danel, F., Hall, L. M., Gur, D., and Livermore, D. M. (1998) Antimicrob. Agents Chemother. 42, 3117-3122.

21. Danel, F., Hall, L. M., Duke, B., Gur, D., and Livermore, D. M. (1999) Antimicrob. Agents Chemother. 43, 1362-1366.

22. Ledent, P., and Frère, J. M. (1993) Biochem. J. 295, 871878.

23. Danel, F. (1997) Ph.D. Thesis, University of London, London.

24. Danel, F., Frère, J.-M., and Livermore, D. M. (2001) Biochem. Biophys Acta 1546, 132-142.

25. Manning, L. R., Dumoulin, A., Jenkins, W. T., Winslow, R. M., and Manning, J. M. (1999) Methods Enzymol. 306, 113129.

26. Leatherbarrow, R. J. (1998) Graphit, version 4.0, Erithacus Software Ltd., Staines, U.K.

27. Wiseman, T., Williston, S., Brandts, J. F., and Lin, L. N. (1989) Anal. Biochem. 179, 131-137.

28. Indyk, L., and Fisher, H. F. (1998) Methods Enzymol. 295, 350-364.

29. Palleroni, N. J. (1984) in Bergey's manual of systemic bacteriology (volume 1) Family 1: Pseudomonadaceae (Krieg, N. R., Ed.) pp 141-199, Williams and Wilkins, Baltimore.
30. Hazelbauer, G. L. (1979) in Bacterial outer membrane permeability (Inouye, M., Ed.) pp 449-473, Wiley, New York.

31. Nikaido, H. (1979) in Bacterial outer membrane permeability (Inouye, M., Ed.) pp 361-407, Wiley, New York.

32. Hobot, J. A., Carlemalm, E., Villiger, W., and Kellenberger, E. (1984) J. Bacteriol. 160, 137-143.

33. Schwarz, H., and Koch, A. L. (1995) Microbiology 141, 31613170 .

34. Matthew, M. (1978) FEMS Microbiol. Lett. 4, 241-244.

35. Good, N. (1975) in Handbook of biochemistry and molecular Biology, 3rd Edition (Volume 1): Physical and biochemistry data (Fasman, G. D., Ed.) pp 367-369, CRC press, Cleveland.

36. Abril, A. M,, Salas, M., Andreu, J. M., Hermoso, J. M., and Rivas, G. (1997) Biochemistry 36, 11901-11908.

37. Glusker, J. P. (1991) Adv. Protein Chem. 42, 1-76.

38. Philippon, A. M., Paul, G. C., and Jacoby, G. A. (1983) Antimicrob. Agents Chemother. 24, 362-369.

39. Livermore, D. M., Maskell, J. P., and Williams, J. D. (1984) Antimicrob. Agents Chemother. 25, 268-272.

40. Templeton, D. M., Sunderman, F. W., Jr., and Herber, R. F. (1994) Sci. Total Environ. 148, 243-251.

41. Pleban, P. (1980) Science 208, 520.

42. Rukgauer, M., Klein, J., and Kruse-Jarres, J. D. (1997) J. Trace Elem. Med. Biol. 11, 92-98.

43. Hechler, U., van den Weghe, M., Martin, H. H., and Frère, J. M. (1989) J. Gen. Microbiol. 135, 1275-1290.

44. Dale, J. W., and Smith, J. T. (1976) Biochem. Biophys. Res. Commun. 68, 1000-1005.

BI0025969 